\title{
Physical activity levels during work, leisure time and transport and its association with obesity in urban slum of Mumbai, India
}

\author{
Kalpak S. Kadarkar ${ }^{1}$, Shraddha R. Tiwari ${ }^{1}$, Gajanan D. Velhal ${ }^{2}$, Purushottam A. Giri ${ }^{3}$
}

\begin{abstract}
${ }^{1}$ Department of Community Medicine, Government Medical College, Aurangabad, Maharashtra, India
${ }^{2}$ Department of Community Medicine, Topiwala National Medical College, Mumbai, Maharashtra, India

${ }^{3}$ Department of Community Medicine, IIMSR Medical College, Badnapur, Jalna, Maharashtra, India
\end{abstract}

Received: 17 January 2016

Accepted: 16 February 2016

\section{*Correspondence:}

Dr. Kalpak S. Kadarkar,

E-mail:kalpaksk@gmail.com

Copyright: (C) the author(s), publisher and licensee Medip Academy. This is an open-access article distributed under the terms of the Creative Commons Attribution Non-Commercial License, which permits unrestricted non-commercial use, distribution, and reproduction in any medium, provided the original work is properly cited.

\begin{abstract}
Background: Rapid changes in urbanization and associated mechanization and sedentary jobs increase the level of physical inactivity in the population. Physical inactivity is directly reflected in the growing burden of obesity in the Indian population predominantly in the urban areas. WHO developed STEP wise approach for surveillance of risk factors for non-communicable diseases. This study aimed at assessing prevalence of overweight, generalized obesity, abdominal obesity and physical activity status and find out association between them among urban slum population of Mumbai.

Methods: Community based, cross-sectional epidemiological study was carried out in urban slum of Mumbai, India during the period of March 2013 to January 2014 by using WHO STEP wise approach. Total number of 600 participants of age group 25-64 years were interviewed and examined for information regarding physical activity and obesity.

Results: About $60 \%$ of study participants were physical inactivity during work, leisure time and transport. Physical inactivity increased with increased age and female sex. Prevalence of overweight or obesity (generalized obesity) $41.8 \%$ was more than that of abdominal obesity $37.7 \%$. Physical inactivity during work, leisure time and transport was significantly associated with obesity and high waist circumference.

Conclusions: Physical inactivity was more so with increasing obesity, women and increasing age. To tackle the epidemic of obesity habitual moderate physical activity is the key. It is necessity of time to create environment for adoption of healthy lifestyle through properly channelled health education and advocacy.
\end{abstract}

Keywords: Physical activity, Non-communicable diseases, Leisure time, Obesity, WHO STEPS

\section{INTRODUCTION}

Physical activity is a key determinant of energy expenditure, and thus is fundamental to energy balance and weight control. A physically active life reduces the risk of coronary heart disease, type 2 diabetes, stroke, colon cancer and breast cancer. ${ }^{1}$ Thirty minutes of moderate-intensity physical activity five days per week is the minimum recommended to level of physical activity. ${ }^{2}$ However, rapid changes in urbanization and associated mechanization and sedentary jobs increase the level of physical inactivity in the population. Globally 3.2 million deaths each year attributed to insufficient physical activity. ${ }^{3}$ The World Health Survey which used standardized questionnaires reported that, overall in India, $29 \%$ of the population were having inadequate physical activity (in all domains of life) particularly in the older age groups. ${ }^{4}$

Physical inactivity and inappropriate nutrition are directly reflected in the growing burden of overweight in the Indian population predominantly in the urban areas. 
Almost 30-65\% of adult urban Indians are reported to be either overweight or obese or have central obesity. ${ }^{5}$ Projection studies show that prevalence of overweight is expected to rise from $12.9 \%$ (134.8 million) in 2005 to $27.8 \%$ (290.7 million) by the year 2030 . Similarly obesity figures will raise from $4.0 \%$ (42.2 million) in 2005 to $5.0 \%$ (52.1 million) by the year $2030 .^{6}$ The prevalence of central obesity as high as $72 \%$ in urban men and $40 \%$ in urban women. ${ }^{7}$

WHO developed STEP wise approach for surveillance of risk factors for non-communicable diseases. ${ }^{8}$ This approach standardized protocols and instruments for surveillance. Findings from these surveys are useful for community based intervention. Rapid urbanization causes increase in population living in urban slums. Urban slum population expose to urbanized lifestyle which places them at a higher risk for NCDs. This study aimed at assessing prevalence of overweight, generalized obesity, abdominal obesity and physical activity status and find out association between them among urban slum population of Mumbai, India.

\section{METHODS}

This was a cross-sectional, community based; descriptive epidemiological study was carried out in an urban slum of Mumbai which was also a field practice area of urban health center of medical college. Study was conducted during the period of March 2013 to January 2014. Male and female belonged to age group of 25-64 years residing in urban slum for more than six months and who were willing to participate and give consent for same were included in study.

Based on report of World Health Organization on 'physical inactivity: a global public health problem' for South-East Asia region, $16 \%$ prevalence of physical inactivity was considered for the study. ${ }^{3}$ By using formula for sample size calculation $\left[n=4 \mathrm{pq} / \mathrm{l}^{2}\right]$, where ' 1 ' is admissible error which is $20 \%$ of 'p', we got sample size of 525 which was rounded off to 600. The study included male and female in the age group of 25-64 years and this age group was further stratified in to four age and sex categories, each stratum with 10 years interval. There were 150 individuals ( 75 male and 75 female) in each of these strata, with this the total sample size of study came to 600. As the study area comprises of 50 plots and each plot consist of nearly 180 households. We had selected 12 households by simple random sampling technique (table of random numbers) from each plot. When any house was found locked, or inclusion criteria not fulfilled then the consecutive house was targeted. From each house one individual was interviewed according to need.

WHO STEPS guidelines and questionnaire were adopted and used for this study. After taking written informed consent participants were interviewed using prestructured and pretested questionnaire based on WHO STEP-1 (interview) and STEP-2 (physical examination) approaches for physical activity and obesity surveillance. ${ }^{8}$ STEP-1 includes core and expanded information on vigorous, moderate and low intensity physical activity during work, leisure time and transport. Criteria for classification of physical activity according to their duration and type were adopted from STEPS guidelines. In STEP-2 height, weight, waist circumference was recorded. Body mass index (BMI) was calculated.

\section{Definitions}

Overweight was defined as a BMI $\geq 23 \mathrm{~kg} / \mathrm{m}^{2}$ but $<25$ $\mathrm{kg} / \mathrm{m}^{2}$ for both genders (based on the World Health Organization Asia Pacific Guidelines) with or without abdominal obesity (AO). ${ }^{9}$

Generalized obesity (GO) was defined as a BMI $\geq 25$ $\mathrm{kg} / \mathrm{m}^{2}$ for both genders (based on the world health oirganization Asia Pacific Guidelines) with or without abdominal obesity (AO). ${ }^{9}$

Abdominal obesity (AO) was defined as a waist circumference $(W C) \geq 90 \mathrm{~cm}$ for men and $\geq 80 \mathrm{~cm}$ for women with or without GO. ${ }^{10}$

Operational definitions for classification of physical activity according to their duration and intensity were adopted from WHO STEPS guidelines. ${ }^{8}$

Instruments for anthropometric measurements were standardized and routinely calibrated. Height was measured with a standard tape to the nearest $0.1 \mathrm{~cm}$ and weight was measured using a standard balance to the nearest $0.5 \mathrm{~kg}$. Participants were requested to stand bare foot and upright with back against wall, heels together. Data collection was started after institutional ethical committee approval. Socio economic status of the study population was determined as per the Modified Prasad's classification April 2013. ${ }^{11}$ Statistical significance was set at $\mathrm{P} \leq 0.05$. Results were analyzed by using Statistical Package of Social Sciences (SPSS) version 16.0.

\section{RESULTS}

In the present study, physical inactivity was prevalent in more than half of study population and was related with increasing prevalence of obesity. Table 1 shows the socio-demographic characteristics of study participants. A total of 600 participants between age 25-64 years were surveyed for prevalence of physical inactivity and its association with obesity under this study. About 54\% participants were educated up to secondary education and nearly $15 \%$ were illiterate. As urban slum community consist mainly of Muslim population and therefore $77 \%$ of participants belonged to Muslim religion, followed by other. Average per capita income was 1427.5 \pm 864.7 Indian national rupees. Most of participant belonged to socio-economic class IV.

Physical activity status among men and women during work, leisure time and transport is shown in Table 2. About sixty percent of study participants were physical 
inactivity (sedentary activity) during work, leisure time and transport. Sedentary activity was more in women when compared to men in all three above mentioned scenarios. Moderate and vigorous activities were more prevalent in men compared to women. In study population $14-16 \%$ of men and $11-13 \%$ of women were doing vigorous activities. About $40 \%$ participants had the habit of walking/ cycling for short distance. Almost $60 \%$ participants were using motor vehicle for short travel. Overall physical inactivity was more in women but the difference is not statistically significant.

Table 1: Socio-demographic profile of study population $(n=600)$.

\begin{tabular}{|c|c|c|c|c|c|c|}
\hline \multirow{2}{*}{\multicolumn{2}{|c|}{ Socio-demographic variables }} & \multicolumn{4}{|c|}{ Age (years) } & \multirow{2}{*}{$\begin{array}{l}\text { Total no. of } \\
\text { participants }\end{array}$} \\
\hline & & $25-34$ & $35-44$ & $45-54$ & $55-64$ & \\
\hline \multirow{3}{*}{ Sex } & Male (\%) & $75(50)$ & $75(50)$ & $75(50)$ & $75(50)$ & $300(50)$ \\
\hline & Female $(\%)$ & $75(50)$ & $75(50)$ & $75(50)$ & $75(50)$ & $300(50)$ \\
\hline & Total & 150 & 150 & 150 & 150 & 600 \\
\hline \multirow{4}{*}{ Religion } & Hindu (\%) & $33(22)$ & 37 (24.7) & $25(16.7)$ & $32(21.3)$ & $127(21.2)$ \\
\hline & Muslim (\%) & $114(76)$ & $111(74)$ & $120(80)$ & $117(78)$ & $462(77)$ \\
\hline & Other $(\%)$ & $3(2)$ & $2(1.3)$ & $5(3.3)$ & $1(0.7)$ & $11(1.8)$ \\
\hline & Total & 150 & 150 & 150 & 150 & 600 \\
\hline \multirow{6}{*}{$\begin{array}{l}\text { Educational } \\
\text { status }\end{array}$} & Illiterate $(\%)$ & $9(6)$ & $27(18)$ & $22(14.7)$ & $30(20)$ & $88(14.7)$ \\
\hline & Primary $(\%)$ & $12(8)$ & $19(12.7)$ & $13(8.7)$ & $21(14)$ & $65(10.8)$ \\
\hline & Secondary (\%) & $84(56)$ & $72(48)$ & $87(58)$ & $81(54)$ & $324(54)$ \\
\hline & High school completed (\%) & $35(23.3)$ & $26(17.3)$ & $19(12.7)$ & $13(8.7)$ & $93(15.5)$ \\
\hline & Graduate $(\%)$ & $10(6.7)$ & $6(4)$ & $9(6)$ & $5(3.3)$ & $30(5)$ \\
\hline & Total & 150 & 150 & 150 & 150 & 600 \\
\hline \multirow{6}{*}{$\begin{array}{l}\text { Socio- } \\
\text { economic } \\
\text { status }\end{array}$} & Class $1(\%)$ & $2(1.3)$ & $6(4)$ & $3(2)$ & $1(0.7)$ & $12(2)$ \\
\hline & Class $2(\%)$ & $21(14)$ & $12(8)$ & $21(14)$ & $27(18)$ & $81(13.5)$ \\
\hline & Class $3(\%)$ & 28 (18.7) & $21(14)$ & $49(32.7)$ & $40(26.7)$ & $138(23)$ \\
\hline & Class $4(\%)$ & $93(62)$ & $96(64)$ & $60(40)$ & $59(39.3)$ & $308(51.3)$ \\
\hline & Class $5(\%)$ & $6(4)$ & $15(10)$ & $17(11.3)$ & $23(15.3)$ & $61(10.2)$ \\
\hline & Total & 150 & 150 & 150 & 150 & 600 \\
\hline
\end{tabular}

Table 2: Prevalence of physical activity status among men and women $(n=600)$.

\begin{tabular}{|lllll|}
\hline Physical Activity & $\begin{array}{l}\text { Men } \\
(\%)\end{array}$ & $\begin{array}{l}\text { Women } \\
(\%)\end{array}$ & $\begin{array}{l}\text { Total } \\
(\%)\end{array}$ \\
\hline \multirow{3}{*}{$\begin{array}{l}\text { During } \\
\text { work }\end{array}$} & Sedentary & $\begin{array}{l}172 \\
(57.3)\end{array}$ & $\begin{array}{l}193 \\
(64.3)\end{array}$ & $\begin{array}{l}365 \\
(60.8)\end{array}$ \\
\cline { 2 - 5 } & \multirow{2}{*}{ Moderate } & $\begin{array}{l}85 \\
(28.3)\end{array}$ & $\begin{array}{l}73 \\
(24.3)\end{array}$ & $\begin{array}{l}158 \\
(26.3)\end{array}$ \\
\cline { 2 - 5 } & \multirow{2}{*}{ Vigorous } & $\begin{array}{l}43 \\
(14.3)\end{array}$ & $\begin{array}{l}34 \\
(11.3)\end{array}$ & $\begin{array}{l}77 \\
(12.8)\end{array}$ \\
\hline \multirow{4}{*}{$\begin{array}{l}\text { During } \\
\text { leisure } \\
\text { time }\end{array}$} & \multirow{2}{*}{ Sedentary } & $\begin{array}{l}180 \\
(60)\end{array}$ & $\begin{array}{l}188 \\
(62.7)\end{array}$ & $\begin{array}{l}368 \\
(61.3)\end{array}$ \\
\cline { 2 - 5 } & \multirow{2}{*}{ Moderate } & $\begin{array}{l}82 \\
(27.3)\end{array}$ & $\begin{array}{l}71 \\
(23.7)\end{array}$ & $\begin{array}{l}153 \\
(25.5)\end{array}$ \\
\cline { 2 - 5 } & \multirow{2}{*}{ Vigorous } & $\begin{array}{l}38 \\
(12.7)\end{array}$ & $\begin{array}{l}41 \\
(13.7)\end{array}$ & $\begin{array}{l}79 \\
(13.2)\end{array}$ \\
\hline \multirow{4}{*}{$\begin{array}{l}\text { During } \\
\text { transport }\end{array}$} & Sedentary & $\begin{array}{l}175 \\
(58.3)\end{array}$ & $\begin{array}{l}185 \\
(61.7)\end{array}$ & $\begin{array}{l}360 \\
(60)\end{array}$ \\
\cline { 2 - 5 } & \multirow{2}{*}{ Moderate } & $\begin{array}{l}77 \\
(25.7)\end{array}$ & $\begin{array}{l}78 \\
(26)\end{array}$ & $\begin{array}{l}155 \\
(25.8)\end{array}$ \\
\cline { 2 - 5 } & Vigorous & $\begin{array}{l}48 \\
(16)\end{array}$ & $\begin{array}{l}37 \\
(12.3)\end{array}$ & $\begin{array}{l}85 \\
(14.2)\end{array}$ \\
\hline
\end{tabular}

Prevalence of various types of obesity according to age and gender is shown in Table 3. Prevalence of overweight or obesity (generalized obesity) $(41.8 \%)$ was more than that of abdominal obesity (37.7\%). Prevalence of overweight or obesity among men and women increased with age till age group 45-54 years and then it declined. In all age groups proportion of overweight or obesity was more in women as compared to men but differences were not found to be statistically significant. Similar trend according to age and gender was noted in case of abdominal obesity. Prevalence of abdominal obesity was less than generalized obesity in all age groups in both genders but in age group of 54-65 years it was more than generalized obesity.

As Table 4 highlights prevalence of physical inactivity among men and women according to their BMI and WC. The majority of the obese men and women in all three scenarios of physical activities i.e. during work, leisure time and transport were physically inactive or sedentary. During work physical inactivity was common overall in $84.3 \%$ of obese men and $86.8 \%$ of obese women. Also the prevalence of sedentary behavior among participants 
with high WC was more in women compared to men during work, leisure time and transport. Prevalence of sedentary behavior during leisure time was higher than that found at work and transport among men and women with high WC or high BMI. Physical inactivity during work, leisure time and transport was significantly associated with obesity, high waist circumference and high waist to hip ratio ( $\mathrm{p}$ value $<0.001$ ).

Table 3: Prevalence of obesity according to age and gender $(n=600)$.

\begin{tabular}{|lllllll|}
\hline $\begin{array}{l}\text { Age groups } \\
\text { (years) }\end{array}$ & Obesity or overweight (generalized obesity) & \multicolumn{4}{l|}{ Abdominal obesity } & Total \\
\hline $25-34$ & Men & Women & Total & Men & Women & Tot \\
\hline $35-44$ & $25(33.3)$ & $27(36)$ & $52(34.7)$ & $21(28)$ & $25(33.3)$ & $46(30.7)$ \\
\hline $45-54$ & $31(41.3)$ & $35(46.7)$ & $66(44)$ & $25(33.3)$ & $29(38.7)$ & $54(36)$ \\
\hline $54-65$ & $34(45.3)$ & $41(54.7)$ & $75(50)$ & $30(40)$ & $35(46.7)$ & $65(43.3)$ \\
\hline Total & $28(37.3)$ & $30(40)$ & $58(40)$ & $29(38.7)$ & $32(42.7)$ & $61(40.7)$ \\
\hline
\end{tabular}

Table 4: Prevalence of physical inactivity among men and women according to their BMI and WC.

\begin{tabular}{|c|c|c|c|c|c|}
\hline & & & \multicolumn{3}{|c|}{ Physical inactivity $^{\mathbf{a}}$} \\
\hline & & & During work & During leisure time & During transport \\
\hline \multirow{4}{*}{$\begin{array}{l}\text { Men } \\
(n=300)\end{array}$} & \multirow{2}{*}{ BMI } & Obese or overweight $(n=118)$ & $99 / 118(84.3)^{*}$ & $106 / 118(89.6)^{*}$ & $103 / 118(87.2)^{*}$ \\
\hline & & Non obese $(n=182)$ & $73 / 182(40.1)$ & $74 / 182(40.7)$ & $72 / 182(39.6)$ \\
\hline & \multirow{2}{*}{ WC } & $\operatorname{High}(n=105)$ & $86 / 105(81.6)^{*}$ & $91 / 105(86.3)^{*}$ & $88 / 105(84.2)^{*}$ \\
\hline & & Normal $(n=195)$ & $86 / 195(44.1)$ & $89 / 195(45.6)$ & $87 / 195(44.6)$ \\
\hline \multirow{4}{*}{$\begin{array}{l}\text { Women } \\
(n=300)\end{array}$} & \multirow{2}{*}{ BMI } & Obese or overweight $(n=133)$ & $115 / 133(86.8)^{*}$ & $124 / 133(93.5)^{*}$ & $119 / 133(89.1)^{*}$ \\
\hline & & Non obese $(n=167)$ & $78 / 167(46.7)$ & $64 / 167(38.3)$ & $66 / 167(39.5)$ \\
\hline & \multirow{2}{*}{ WC } & $\operatorname{High}(\mathrm{n}=121)$ & $101 / 121(83.1)^{*}$ & $106 / 121(87.2)^{*}$ & $105 / 121(86.7)^{*}$ \\
\hline & & Normal $(n=179)$ & $92 / 179(51.4)$ & $82 / 179(45.8)$ & $80 / 179(44.7)$ \\
\hline
\end{tabular}

Values in parenthesis are percentages; BMI: Body mass index; WC: Waist circumference; *P value <0.001; 'P' value was calculated by comparison of sedentary and non-sedentary, among 1 .obese or overweight and non-obese or non-overweight subjects; 2 . High waist circumference and normal WC by Chi-square test; ${ }^{a}$ Physical inactivity refers to participants with sedentary behaviour

\section{DISCUSSION}

Varied findings according to region, gender, age and socioeconomic conditions were noted in several studies done on physical activity and obesity. In this study, sedentary behavior was prevalent in about $60 \%$ of subjects. Higher prevalence of sedentary behavior was noted in women as compared to men during work, leisure time and transport. Similar trend was found in study done by Singh et al which showed that sedentary behavior was prevalent in $59.3 \%$ of women and $58.5 \%$ of men. ${ }^{12}$ Study done by Meenakshi, et al in Jaipur reported higher prevalence $(>71 \%)$ of sedentary behavior than this study. ${ }^{13}$ Lower prevalence of sedentary behavior reported by study done by Sugathan, et al in Kerala as compared to present study. ${ }^{14}$

The combined prevalence of overweight and obesity in urban slum of Mumbai was found to be $41.8 \%$, of these, women showed a higher prevalence $(44.3 \%)$ as compared to men $(39.3 \%)$. National family health survey 3 showed prevalence of overweight or obesity in urban area was
$23.5 \%$ for women and $15.9 \%$ for men. ${ }^{15}$ This is less than that seen in present study. Though the findings in current study is higher than national average, it is lowered than that found in national health surveys of developed countries United states and Australia. ${ }^{16}$ Age and gender are biological non-modifiable factors affecting obesity status. In current study it was found that prevalence of overweight or obesity increased with age with highest prevalence noted in age group 45-54 years and then it declined. This decline may be attributed to decreased absorption from intestines and decreased calorie intake. Similar trend was noted in study done by Mishra, et al. ${ }^{17}$ In current study it was observed that the prevalence of overweight or obese was higher in women as compared to men. Findings of studies conducted in India by Mishra, et al, Singh, et al and NFHS-3 also revealed similar trend among women and men. ${ }^{12,15,17}$ This may be due to physiological and hormonal differences between to genders and also varied effects of socio-cultural factors. The prevalence of abdominal obesity was $37.7 \%$ and it was alarming to note that women had higher prevalence $(40.3 \%)$ than men $(35 \%)$. Similar trend was noted in 
studies done by Meenakshi, et al and Thankappan, et al. $^{13,18}$

It was evident from current study that sedentary behavior was significantly associated with all types of obesity i.e. generalized and abdominal obesity in both sexes. Similar findings and associations were noted in the five city study done by Singh, et al in India. ${ }^{12}$ Prevalence of sedentary behavior during leisure time was higher than that found at work and transport among men and women with abdominal obesity or high BMI. Present study findings revealed that abdominal obesity was as common as combined overweight or generalized obesity. With increase in physical activity, the prevalence of high waist circumference and overweight decreased which was statistically significant.

\section{CONCLUSION}

From this study we conclude that physical inactivity or sedentary behavior was more so with increasing obesity, women and increasing age. Increased urbanization has resulted in several environmental factors (i.e. lack of parks, lack of sports/ recreation facilities, pollution, mechanization of various activities etc.) may discourage participation in physical activity. To tackle the epidemic of obesity habitual moderate physical activity is the key. It is necessity of time to create environment for adoption of healthy lifestyle through properly channeled health education and advocacy.

\section{ACKNOWLEDGEMENTS}

Authors would like to express their deep sense of gratitude to the Dr. S. R. Suryawanshi, HOD, Department of Community Medicine. They would also acknowledge the help and support of Dr. Yasmeen Kazi, Asst. Professor; Staff of UHTC and Health Post, Shivajinagar and Post Graduate students, Department of Community Medicine, T. N. Medical College, Mumbai during data collection.

\section{Funding: No funding sources}

Conflict of interest: None declared

Ethical approval: The study was approved by the Institutional Ethics Committee

\section{REFERENCES}

1. WHO. Global strategy on Diet, Physical activity and Health. 2009. Available at http://www who.int/dietphysicalactivity/pa/en/index html [accessed on 12 January 2016].

2. WG-3(2): Non Communicable Diseases. Report of the Working Group on Disease Burden for 12th Five Year Plan. New Delhi: Planning Commission, Government of India. 2011:65.

3. WHO. Global strategy on Diet, Physical activity and Health. Available at http://www.who.int/ dietphysicalactivity/factsheet_inactivity/en/accessed on 30 January 2013.

4. International Institute for Population Sciences, World Health Organization, World Health Organization (WHO)-India-WR Office. World Health Survey, 2003 INDIA. Mumbai: IIPS. 2006;XXII.

5. Misra A, Khurana L. Obesity and the metabolic syndrome in developing countries. J Clin Endocrinol Metab. 2008;93(11):S9-30.

6. Kelly T, Yang W, Chen CS, Reynolds K, He J. Global burden of obesity in 2005 and projections to 2030. Int J Obes (Lond). 2008;32(9):1431-7.

7. ICMR Taskforce. Collaborative Study of coronary heart diseases. ICMR Taskforce. 1996;40-72.

8. World Health Organization. The WHO STEP wise approach to Surveillance of non-communicable diseases (STEPS). Geneva: World Health Organization. Available at: http://www.who.int/ ncd_surveillance/en/, [accessed on 2 march 2013].

9. Harrison GG, Buskirk ER, Lindsay Carter ER. Skinfold thickness and measurement technique. In: Lohman TG, Roche AF, Martorell R, editors. Anthropometric standardization reference manual. Champaign, IL: Human Kinetics Books. 1988:5570.

10. The Asia Pacific perspective: redefining obesity and its treatment. Regional Office for the Western Pacific (WPRO), World Health Organization. International Association for the Study of Obesity and the International Obesity Task Force: St Leonards, Australia; Health communications Australia Pty Limited. 2000:22-9.

11. Sharma R. Revision of Prasad's social classification and provision of an online tool for real-time updating. South Asian Journal of Cancer. 2013;2(3):157.

12. Singh RB , Pella D, Mechirova V, Kartikey K. Five City Study Group. Prevalence of obesity, physical inactivity and under nutrition, a triple burden of diseases during transition in a developing economy. The Five City Study Group. Acta Cardiol. 2007;62:119-27.

13. Meenakshi BM, Somila S, Gautami TS. Risk factors profile of non-communicable diseases among middle-income (18-65 years) free-living urban population of India. Int $\mathrm{J}$ Diab Dev Ctries. 2006;26:169-76.

14. Sughathan TN, Sonam CR, Sunkaranarayana K. Behavioral risk factors for non-communicable diseases among adults in Kerala, India. IJMR. 2008;127:555-63.

15. International Institute for Population Sciences, Macro International. National Family Health Survey (NFHS-3) 2005-06: India. Mumbai: IIPS. 2007:30309.

16. WHO Global Infobase: Search by Country. World Health Organization. Available from: http://www.who.int/infobase. [Accessed on 12 January 2016]. 
17. Mishra A, Pandey RM, Devi JR. High prevalence of diabetes, obesity and dyslipidemia in urban slum population in northern India. Int J Obes Relat Metab Discord. 2001;44:1094-101.

18. Thankappan KR, Bela Shah. Risk factor profile for chronic non-communicable diseases: results of community based study in Kerala, India. IJMR. 2010;131:53-63.
Cite this article as: Kadarkar KS, Tiwari SR, Velhal GD, Giri PA. Physical activity levels during work, leisure time and transport and its association with obesity in urban slum of Mumbai, India. Int $\mathrm{J}$ Community Med Public Health 2016;3:715-20. 